\title{
Commercial hybrid yield of green asparagus (Asparagus officinalis L. var. altilis) processed in two spear-lengths, during the stable productivity stage, in the Province of Buenos Aires, Argentina
}

\author{
A.M. Castagnino 1,2,3,a, K.E. Diaz ${ }^{1}$, M.B. Rosini ${ }^{1}$, A. Guisolis ${ }^{1}$, M.C. Dussi ${ }^{4}$ and W.J. Rogers ${ }^{1,5}$ \\ ${ }^{1}$ CRESCA-FAA-UNICEN, Argentina; ${ }^{2 U C A}$, Argentina; ${ }^{3}$ ASAHO, Argentina; ${ }^{4}$ UNCOMA, Argentina; ${ }^{5}$ CIC-BIOLAB AZUL, \\ CONICET-INBIOTEC, FAA-UNICEN, Argentina.
}

\begin{abstract}
The perennial crop asparagus reaches maximum yield in its fifth season, exhibits marked genotype-environment interaction and requires productivity evaluation of its hybrids. To determine the behavior of green asparagus genotypes, a randomized complete block design trial (begun 16/11/11, density $23810 \mathrm{pl} \mathrm{ha}^{-1}$, area $1690 \mathrm{~m}^{2}$ ) was carried out in Azul (36 $38^{\circ}$ ' S, lat. 59 $51^{\prime}$ W, long.) within the framework of the ISHS's Fourth International Asparagus Cultivar Trial, in which the following hybrids were harvested between $5 / 8 / 17$ and 26/10/17 and evaluated for agronomic performance: 'Italo', 'Vittorio', 'Eros', 'Ercole', 'Giove', 'Franco', 'Chino', 'Early-California', 'UC-157', 'Patrón', 'NJ-1189', 'NJ-1123' and 'NJ-1192'. Their response to pre-harvest diammonium

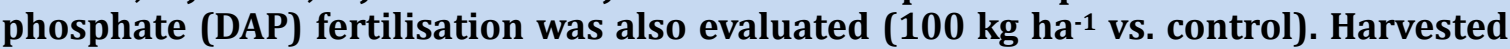
spears were cut, conditioned to two lengths (long $22 \mathrm{~cm}$, short $17 \mathrm{~cm}$ ), weighed, counted, washed and calibrated. The following characters were evaluated: total fresh commercial productivity (TFP) and that of long and short commercial spears (CFP-L and CFP-S); total commercial spear number (TSN) and that of long and short commercial spears (CSN-L and CSN-S); mean spear weight (MSW); calibre distribution (CD): (J: Jumbo; XL: Extra-Large; L: Large; M: Medium; S: Small and A: Asparagine). ANOVA-LSD test $P \geq 0.05$ was employed. DAP fertilisation raised yield by $3-10 \%$, though not significantly. The following mean values were obtained: TFP: $8678.46 \mathrm{~kg} \mathrm{ha}^{-1}$; TSN:

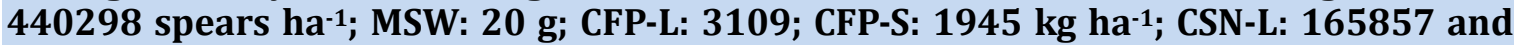
CSN-S: 130467 spears ha-1. The following hybrids performed well: for CFP-L: 'Vittorio': 4379(a); 'Franco': 4033(ab); 'NJ-1123': 3849(abc); for CFP-C: 'NJ-1123': 2726(a); 'Ercole': 2483(ab); 'Vittorio': 2325(abc); for CSN-L: 'NJ-1123': 225260(a); 'Franco': 214161(a); 'Vittorio': 204358(ab); 'Giove': 200229(abc); for CSN-C: 'NJ-1123': 2725(a); 'Ercole': 2482(ab); 'Vittorio': 2325(abc); for CD: J: 'UC-157': 12767(a); 'Eros': 9882 (ab); 'NJ-1123': 9005(abc); for XL: 'NJ-1123': 41124(a); 'Franco': 38958(ab); 'NJ-1192': 37644(ab); for L: 'Ercole': 85083(a); 'NJ-1123': 84700(a); 'Franco': 83872(a); 'Italo': 83095(a); for M: 'NJ-1123': 118198(a); 'Franco': 116369(a); 'Vittorio': 109645(ab); 'Ercole': 105984(ab); for S: 'Giove': 102748(a); 'NJ-1123': 80530(ab). In summary, 'NJ1123' would be chosen for spear number productivity and 'Vittorio' and 'Franco' for yield.
\end{abstract}

Keywords: all-male hybrids, productivity, spear length, quality, caliber

\section{INTRODUCTION}

Asparagus is a perennial crop that reaches its maximum yield in its fifth year, shows marked genotype-environment interaction and requires evaluation of hybrid productivity throughout the active economic life of the plantations. World production is increasing in both area under cultivation and yield per unit area. In 2016, the global area grown was 1530567 ha with a total production of $872673 \mathrm{~kg} \mathrm{ha}^{-1}$, and a unit mean of $5702 \mathrm{~kg} \mathrm{ha}^{-1}$ (FAO, 2018).

aE-mail: amc@faa.unicen.edu.ar 
The two main types of asparagus globally cultivated are green and white. In the former case, spears are harvested after emerging from the soil, with a mean length generally exceeding $22 \mathrm{~cm}$, or when they reach a minimum of $18 \mathrm{~cm}$ for the commercialisation of asparagus tips, which are currently in demand. In the case of white asparagus, a month before harvest rows are built up to a height of $25-30 \mathrm{~cm}$ above the crown and spears are harvested immediately, they appear above ground, ensuring that the upper bracts do not begin photosynthesis and remain white. The complexity of the management of white asparagus and its raised labor requirement means that the production of green asparagus is far greater.

Besides these types, due to the potential health benefits of flavonoids found in certain vegetables, including asparagus, cultivars with completely violet spears have been developed (Benson et al., 1996; Fallon and Andersen, 1999), which also allows the diversity of the types of asparagus on offer to be widened.

Regarding productivity and quality, diverse factors can affect them, such as the genetic, environmental, agricultural and harvesting conditions, as well as post-harvesting conditions and management that have been widely analyzed by Lipton (1990). One of the most important aspects of quality throughout the life of a plantation is the distribution of spear calibre, where the lowest diameter that can be commercialised is $3 \mathrm{~mm}$ for green and violet asparagus (Siomos, 2018).

According to numerous authors, the consumption of asparagus is beneficial for health. Specifically, a total of 123 volatile compounds have been detected in fresh asparagus (Ulrich et al., 2001; Ulrich and Hoberg, 2002), where the principal components are C6 aldehydes (hexanal and trans-2-hexenal) and alcohols (such as 1-octen-3-ol), representing up to $91 \%$ of the volatile compounds; ketones, alkenes and terpenes, though in much lower quantity, were also detected, providing the aroma characteristic of fresh asparagus and, together with sweet and bitter components (sugars, organic acids, phenolics and saponins), contribute toward its typical flavour. Due to the importance of this latter aspect, 18 sensorial characteristics have been defined to describe it (Hoberg et al., 1999; Siomos, 2018). Other nitrogen and sulfur compounds in fresh asparagus are also important, since, upon thermal degradation during cooking, different volatile compounds are generated that contribute to the aroma of consumed asparagus (Ulrich et al., 2001; Siomos, 2018).

Asparagus contains fiber, vitamin C, vitamin B1 (thiamine) and vitamin B6, is low in fat, contains no cholesterol and is very low in calories; it provides potassium and small quantities of fluorine, copper, zinc, manganese and iodine; it is one of the richest products in glutathione, among the top five fruit and vegetables (Jones et al., 1992; Mills et al., 1997; Demirkol et al., 2004; Qiang et al., 2005; Zacharis et al., 2011), which, according to the US's National Cancer Institute (Minagri, 2016), is of fundamental importance in combating cancer (glutathione is present in high concentrations in the liver, acting as a detoxifying agent that combines with undesirable substances to be excreted via the urinary system; it is required by the immune system in at least two ways: lymphocyte multiplication and antioxidant production); asparagus is also rich in folic acid (B-complex vitamin), needed to produce the cells required for tissue growth and repair, and with a role in preventing birth defects in the brain and spinal cord (neural tube defects) if consumed before and during the first weeks of pregnancy.

Asparagus is characterized by containing bioactive compounds beneficial for health in significant concentrations, such as rutin (a flavonoid derivative of the flavonol quercetin), protodioscin, furostanol saponin and glutathione (Demirkol et al., 2004; Schwarzbach et al., 2006; Chin and Garrison, 2008; Demrkol, 2009; Siomos, 2018).

In the case of rutin, it is the most abundant polyphenolic compound in green asparagus (Chin and Garrison, 2008; Fuentes-Alventosa et al., 2008; Guillén et al., 2008; Fanasca et al., 2009; Maeda et al., 2010; Motoki et al., 2012; Siomos, 2018). It also contains 100-460 mg.kg-1 glutathione, varying in concentration for different cultivars, spear calibres and spear portion (base and tip) (Mills et al., 1997; Saito et al., 2000; Demirkol et al., 2004; Qiang et al., 2005; Drinkwater et al., 2014). Some other phenolic compounds, such as anthocyanins, hydroxycinnamic acid and fatty acids (Chin et al., 2002; Guillén et al., 2008), carotenoids and vitamins E and C (Chin et al., 2002; Demirkol et al., 2004; Fanasca et al., 2009; Lee et al., 2010) are also important, nutritionally and as antioxidants (Chin et al., 2002; Rodríguez et al., 2005; 
Maeda et al., 2008; Rodkiewicz, 2008). These healthy nutritional characteristics are all the more attractive given the increasing interest in consuming beneficial food components, favoring buying decisions in the consumer (Chin and Garrison, 2008; Fuentes-Alventosa et al., 2008).

As a crop, asparagus is perennial, whose production and quality are significantly affected by a series of factors, notably genetic, environmental and management aspects. In particular, considerable genetic variation has been observed for spear yield and calibre distribution. It is a dioecious species, of increasing productivity over the years, for which allmale F1 hybrids have been widely grown over the last decades (Siomos, 2018), due to their higher and earlier productivity compared to female plants, although of lower calibre (González Castañón, 1990), but higher in rutin (Han et al., 2008).

Currently, breeding programmes are focused upon obtaining high yielding, early genotypes that are disease tolerant and with high quality spears, defined by their appearance (without stains, of intense color, straight, with closed bracts) and calibre, which greatly vary among genotypes. Over the last decade, breeding is achieving increases in the content of the aforementioned bioactive compound content (Stoffyn et al., 2012; Drinkwater et al., 2014; Siomos, 2018).

Given the importance of quality in the obtention of elevated productivity in asparagus, choice of site, genotype and management, including fertilisation, is of fundamental importance. The aim of the current work is to determine the behavior of 13 green asparagus genotypes in a field trial carried out at the Faculty of Agronomy, Azul, Province of Buenos Aires, within the framework of the Fourth International Asparagus Cultivar Trial organized by the International Society for Horticultural Science, evaluating genotypes of different origen, including their response to pre-harvest fertilisation.

\section{MATERIALS AND METHODS}

A trial was carried out at the Experimental Field of the Faculty of Agronomy, Azul ( $36^{\circ} 48^{\prime}$ S lat., $59^{\circ} 51^{\prime}$ W long.) of the National University of the Centre of the Province of Buenos Aires (Universidad Nacional del Centro de la Provincia de Buenos Aires - UNICEN), consisting of the evaluation of the following genotypes: 'Italo', 'Vittorio', 'Eros', 'Ercole', 'Giove' and 'Franco', from Italy; 'Chino' from China; and 'Early-California', 'UC-157', 'Patrón', 'NJ-1189', 'NJ-1123' and 'NJ-1192', from the USA.

The trial was planted on $16 / 11 / 2011$ with a plant density of $23,810 \mathrm{ha}^{-1}$ spaced at 1.4 $\mathrm{m}$ between rows and $0.3 \mathrm{~m}$ between plants. The trial was a randomized complete block design consisting of four blocks with rows $7 \mathrm{~m}$ long. Each block included 15 rows, each one of which corresponded to a plot with 27 plants, with the two lateral rows being guards. The paths between blocks were $4 \mathrm{~m}$ wide, while the header and lateral paths were of $5 \mathrm{~m}$, with the trial occupying a total area of $1690 \mathrm{~m}^{2}$. The soil was typical argiudol without profile impediments, with a slightly acidic $\mathrm{pH}$, normal electrical conductivity $\left(143.5 \mu \mathrm{sm}^{-1}\right)$, moderate to good provision of total nitrogen $(0.183 \%)$; good provision of phosphorus (33.07 ppm, according to the method of Bray and Kurtz) and 3.74\% organic material (method of Walkley and Black). The analyses were carried out by the Soil Analysis Laboratory of the Faculty of AgronomyUNICEN. The study zone has a temperate climate, an annual mean temperature of $15^{\circ} \mathrm{C}$ (summer mean $22^{\circ} \mathrm{C}$, winter mean $8^{\circ} \mathrm{C}$ ) and an annual mean precipitation of $960 \mathrm{~mm}$.

Lot preparation for plantation was initiated various months before and consisted of the use of a disk crawler and a chisel plough. Prior to planting the lot was ploughed again and treated with a moto-cultivator. Rows were cut to a depth of $0.25 \mathrm{~m}$. Weed control consisted of a combination of moto-cultivator, hand-weeding and herbicide application. In pre-plantation, Trifluralina was applied at a dosage of $2 \mathrm{~L} \mathrm{ha}^{-1}$ and incorporated manually, followed by Linurón at $2 \mathrm{~L} \mathrm{ha}^{-1}$. From the second year, a mixture of Metribuzín $\left(\mathrm{C}_{8} \mathrm{H}_{14} \mathrm{~N}_{4} \mathrm{OS} ; 0.5 \mathrm{~kg} \mathrm{ha}^{-1}\right.$ at $\left.35 \%\right)$ and Pendimetalín $\left(\mathrm{C}_{13} \mathrm{H}_{19} \mathrm{~N}_{3} \mathrm{O}_{4} ; 2.5 \mathrm{~L} \mathrm{ha}^{-1}\right.$ at $\left.31.7 \%\right)$ was applied each year at pre-emergence, whereas at post-emergence a mixture of Glyphosate $\left(\mathrm{C}_{3} \mathrm{H}_{8} \mathrm{NO} \mathrm{O}_{5} \mathrm{P}\right)$ and Bentazon $\left(\mathrm{C}_{10} \mathrm{H}_{12} \mathrm{~N}_{2} \mathrm{O}_{3} \mathrm{~S}\right)$ was applied where necessary. Complementary irrigation was carried out by weekly drip-feed during the first two years, according to crop need. Regarding fertilisation, a background dosage of $100 \mathrm{~kg} \mathrm{ha}^{-1}$ (FDA100), of diammonium phosphate $\left(\left(\mathrm{NH}_{4}\right)_{2} \mathrm{HPO}_{4}\right)$ was applied in 
bands of $0.30 \mathrm{~m}$, while urea $\left(\mathrm{CH}_{4} \mathrm{~N}_{2} \mathrm{O}\right)$ was annually broadcast during the vegetative period, with variable dosage depending upon crop phenology stage.

Thirty-four manual harvests were carried out every other day between (05/08/201726/10/2017). Harvesting and fresh processing was carried out following the methodology indicated by the quality green asparagus protocol of the MINAGRI (Ministry of Agriculture) of Argentina (Resolution-SAGPyA N²49/2007).

The sampling unit per plot was of 27 plants and, since there were four blocks in the trial, the total plants harvested per hybrid was 108. Once harvested, the spears were transported immediately to the processing laboratory. The processing sequence was: washing, determination of total weight, determination of total spear number, cutting to $22 \mathrm{~cm}$ (long spears) and $17 \mathrm{~cm}$ (short spears), selection for quality, determination of commercial fresh weight, calibration of the commercial spears, determination of the number of spears per calibre and quantification of the defects in discarded spears and packaging. The commercial spears were classified in the following categories: according to their calibre (diameter $2 \mathrm{~cm}$ from the base): Asparagine (A): $<6 \mathrm{~mm}$; Small (S): 6-9 mm; Medium (M): 9-12 mm; Large (L): 12-16 mm; Extra Large (XL): 16-18 $\mathrm{mm}$; Jumbo (J): $>18 \mathrm{~mm}$, as indicated by the quality protocol mentioned above.

Characters scored were: total fresh commercial productivity (TFP), long and short spear fresh commercial productivity (CFP-L, CFP-S), total commercial spear number (TSN), long and short commercial spear number (CSN-L, CSN-S), mean spear weight (MSW) and calibre distribution, CD (J: Jumbo; XL: Extra-Large; L: Large; M: Medium; S: Small and A: Asparagine). Data analysis was by ANOVA-LSD ( $\geq 0.05)$.

\section{RESULTS AND DISCUSSION}

In the year studied, total productivity was: TFP: $8678 \mathrm{~kg} \mathrm{ha}^{-1}$; TSN: 440298 commercial spears ha-1, where the MSW was $20 \mathrm{~g}^{-1}$ spear $^{-1}$. These results were superior to those of the previous year, in which the following results were obtained: TFP: $5120 \mathrm{~kg} \mathrm{ha}^{-1}$, TSN: 284,910 spears ha-1 and MSW: 18 g spear $^{-1}$, and $68 \%$ of the commercial production corresponded to long spears (Castagnino et al., in press).

Fertilisation carried out with FDA100 had no significant effect on total spear production, in spite of the observed 3\% numerical increase (Figure 1).

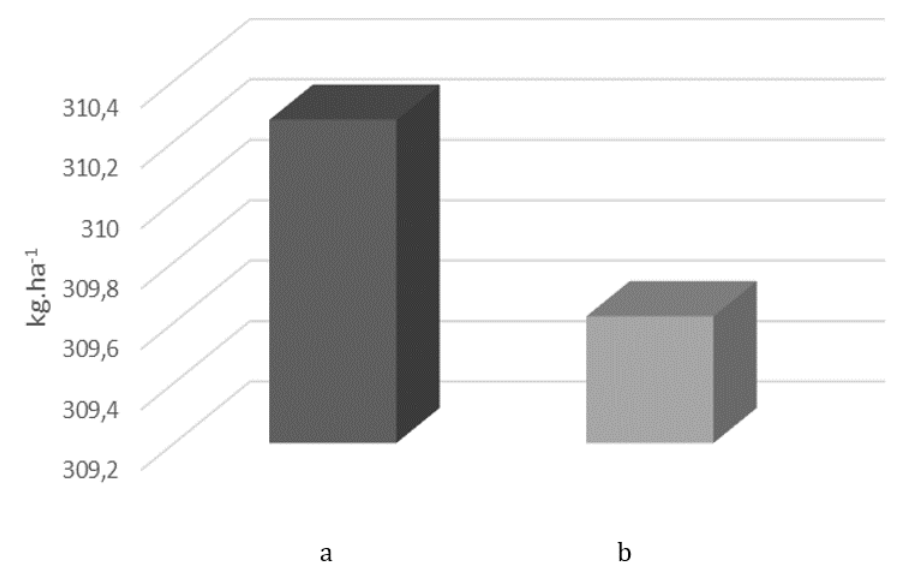

Figure 1. Production of spears (TFP) per harvest of green asparagus (a) with fertiliser and (b) without fertiliser.

For spear production of different lengths, fertilisation again had no significant effect, in spite of the observed numerical difference of $9.5 \%$ ( $8 \%$ for long spears and $11 \%$ for short) (Table 1). 
Table 1. Response to fertilisation with ammonium diphosphate (100 kg ha-1) of hybrids of green asparagus, in Azul, Province of Buenos Aires.

\begin{tabular}{lcccccc}
\hline & $\begin{array}{c}\text { Total } \\
\text { commercial } \\
\text { spear } \\
\text { number }\end{array}$ & $\begin{array}{c}\text { Long } \\
\text { commercial } \\
\text { spear } \\
\text { number }\end{array}$ & $\begin{array}{c}\text { Short } \\
\text { commercial } \\
\text { spear } \\
\text { number }\end{array}$ & $\begin{array}{c}\text { Total fresh } \\
\text { commercial } \\
\text { productivity }\end{array}$ & $\begin{array}{c}\text { Commercial } \\
\text { productivity } \\
\text { long } \\
\text { spears }\end{array}$ & $\begin{array}{c}\text { Commercial } \\
\text { productivity } \\
\text { short } \\
\text { spears }\end{array}$ \\
\cline { 2 - 7 } & TSN & CSN-L & CSN-S & TFP & CFP-L & CFP-S \\
\hline With fertiliser & $447776^{\mathrm{a}}$ & $172269^{\mathrm{a}}$ & $137280^{\mathrm{a}}$ & $8687,6^{\mathrm{a}}$ & $3165,4^{\mathrm{a}}$ & $2046,0^{\mathrm{a}}$ \\
Without fertiliser & $432824^{\mathrm{a}}$ & $159445^{\mathrm{a}}$ & $123654^{\mathrm{a}}$ & $8669,4^{\mathrm{a}}$ & $3052,8^{\mathrm{a}}$ & $1844,1^{\mathrm{a}}$ \\
\hline
\end{tabular}

In the case of productivity per harvest in $\mathrm{kg} \mathrm{ha}^{-1}$, significant differences were neither observed for long and short spears, in spite of the numerical 3\% increase for long spears with fertiliser and $11 \%$ increase for short spears (Figure 2).

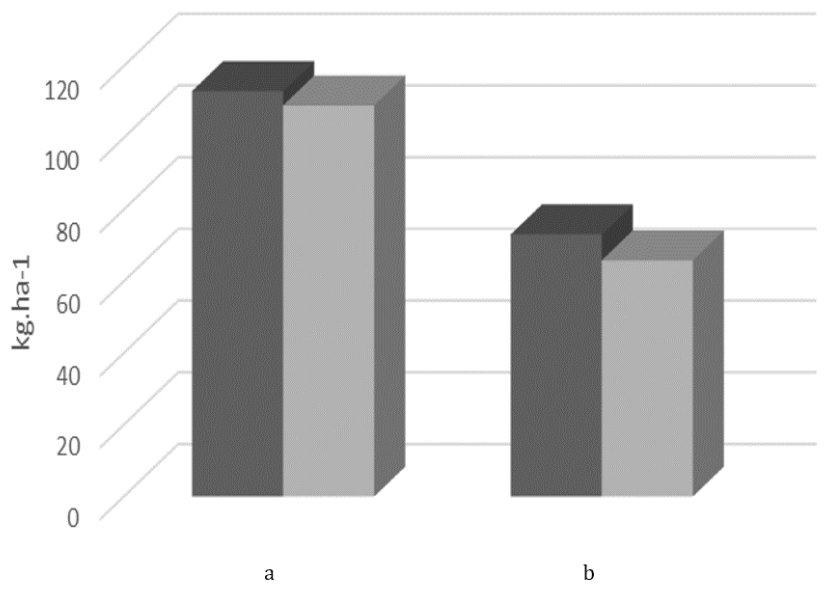

Figure 2. Production per harvest of (a) long (CFP-L) and (b) short (CFP-S) spears of green asparagus. Dark grey with fertiliser, light grey without fertiliser.

In the case of general total commercial production of the trial, the following were obtained: CFP-L: 3109; CFP-S: 1945 kg ha-1; CSN-L: 165857 and CSN-S: 130467 spears ha-1. The absence of significant differences for fertilisation application might be due to the plants, in the immediate productive stage, using the reserves in their roots accumulated in the previous summer, implying that significant differences might be expected in the following production year. This will be part of future work.

Regarding the commercial productivity of long spears, the Italian genotypes generally and the US hybrid 'NJ-1123' gave excellent results, with the following ranking: 'Vittorio': 4379(a); 'Franco': 4033(ab) and 'NJ-1123': $3849 \mathrm{~kg} \mathrm{ha}^{-1}$ (abc); For spears ha-1, 'NJ-1123': 225260(a); 'Franco': 214161(a); 'Vittorio': 204358(ab) and 'Giove': 200229(abc) stood out.

In the case of the productivity of short spears, the following excelled, in the following order: 'NJ-1123': 2726(a); 'Ercole': 2483(ab); 'Vittorio': 2325(abc). For spears ha-1': 'NJ-1123': 2725(a); 'Ercole': 2482(ab); 'Vittorio': 2325(abc) (Table 2).

These results differed for some genotypes compared to the commercial productivity obtained in the previous, i.e. fifth, year of evaluation, in which the following exceeded the mean: 'Vittorio': 6072; 'UC-157': 6006; 'Eros': 5885; 'Franco': 5745; 'NJ-1123': 5573; 'EarlyCalifornia': 5359 and 'NJ-1192': $5284 \mathrm{~kg} \mathrm{ha}^{-1}$. 
Table 2. Commercial spear production of green and purple asparagus of distinct lengths in the sixth year after plantation.

\begin{tabular}{|c|c|c|c|c|c|c|}
\hline Hybrid & $\begin{array}{c}\text { Total } \\
\text { commercial } \\
\text { spear } \\
\text { number }\end{array}$ & $\begin{array}{c}\text { Long } \\
\text { commercial } \\
\text { spear } \\
\text { number }\end{array}$ & $\begin{array}{c}\text { Short } \\
\text { commercial } \\
\text { spear } \\
\text { number }\end{array}$ & $\begin{array}{l}\text { Total fresh } \\
\text { commercial } \\
\text { productivity }\end{array}$ & $\begin{array}{l}\text { Commercial } \\
\text { fresh } \\
\text { productivity } \\
\text { long spears }\end{array}$ & $\begin{array}{c}\text { Commercial } \\
\text { fresh } \\
\text { productivity } \\
\text { short spears }\end{array}$ \\
\hline & TSN & CSN-L & CSN-S & TFP & CFP-L & CFP-S \\
\hline Patron & 216367 & $116888^{e}$ & 99479 ef & 2903,4 & 1745,5 e & $1157,9 \mathrm{f}$ \\
\hline NJ-1189 & 228941 & 127647 de & 101294 ef & 4385,7 & 2692,5 de & 1693,2 def \\
\hline Chino & 221529 & 132588 cde & $88941^{f}$ & 3812,1 & 2506,0 de & 1306,1 ef \\
\hline UC-157 & 263118 & 138353 cde & 124765 cde & 4497,3 & 2718,9 de & 1778,4 cdef \\
\hline Early California & 252412 & 140412 cde & 112000 cdef & 4412,0 & $2610,6 \mathrm{de}$ & 1801,5 cde \\
\hline Eros & 254882 & 144529 cde & 110353 def & 4731,6 & $2926,0 \mathrm{~cd}$ & 1805,6 cde \\
\hline NJ-1192 & 279314 & 152255 bcde & 127059 bcde & 4916,9 & $2932,6 \mathrm{~cd}$ & 1984,3 bcd \\
\hline Italo & 314408 & $177055 \mathrm{abcd}$ & 137352 bcd & 5386,9 & $3376,3 \mathrm{abcd}$ & 2010,6 bcd \\
\hline Ercole & 329481 & 182389 abc & $147093 \mathrm{bc}$ & 5933,9 & 3451,0 abcd & 2482,9 ab \\
\hline Giove & 362796 & $200229 a b$ & $162567 \mathrm{ab}$ & 5436,5 & 3201,7 bcd & 2234,9 abcd \\
\hline Vittorio & 351450 & 204358 ab & 147093 bc & 6704,2 & 4378,6 a & $2325,6 \mathrm{abc}$ \\
\hline Franco & 354445 & 214162 a & $140283 \mathrm{bcd}$ & 6013,7 & $4032,8 \mathrm{ab}$ & 1980,9 bcd \\
\hline NJ-1123 & 422840 & $225278^{a}$ & 197563 a & 6574,4 & $3848,9 \mathrm{abc}$ & $2725,6^{a}$ \\
\hline
\end{tabular}

In the current year, in all cases, the production per harvest of long spears, for both number and $\mathrm{kg} \mathrm{ha}^{-1}$, exceeded that of short spears, as would be expected. Nonetheless, having utilized two cut lengths permitted an increase in the commercial production achieved, minimising discarded waste (Figures 3 and 4).

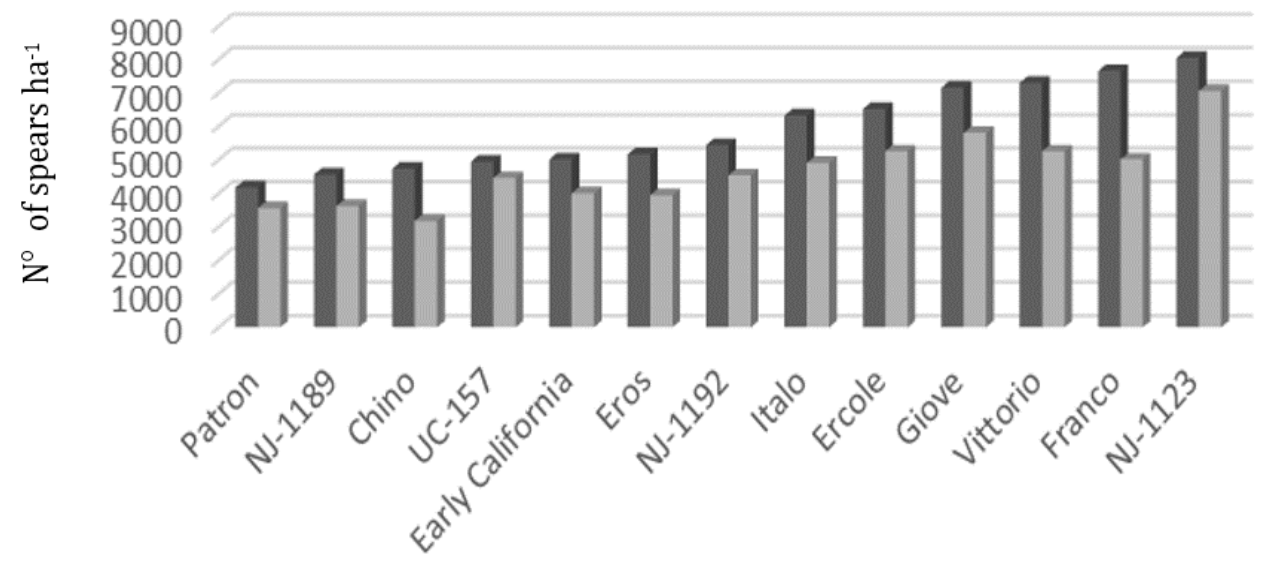

Figure 3. Mean total commercial spear number of green asparagus in the sixth year after plantation. Dark gray long spears (CSN-L), light gray short spears (CSN-S).

These results also differed from those obtained in the first year of harvest, in which 'Patron': 1762(a), NJ-1123: 1346 and 'UC-157': 1340(b), and 'Early California': 1198(bc) kg.ha-1 stood out from the rest; whereas for TSN, the most productive was 'Patron': 118980(a); followed by 'UC-157': 99240(b); 'NJ-1123': 810000(c); 'Early California': 795000. 


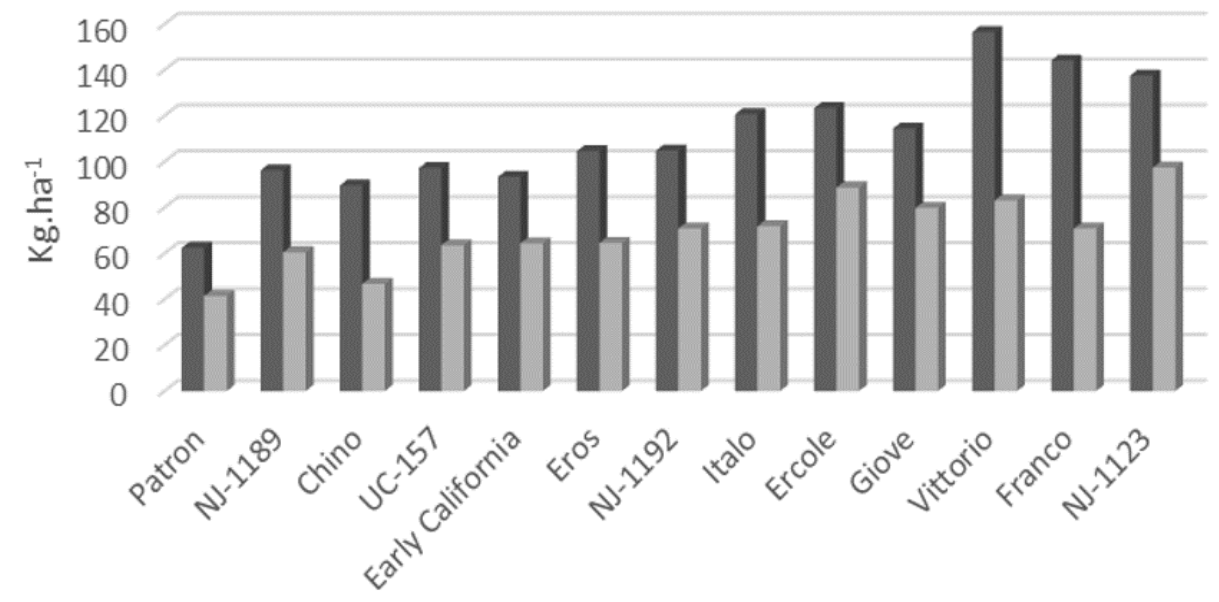

Figure 4. Mean total commercial fresh productivity $\mathrm{kg} \mathrm{ha}^{-1}$ of green asparagus in the sixth year after plantation. Dark gray long spears (CFP-L), light grey short spears (CFPS).

For calibre distribution (CD), a third of the spears were classified in the larger calibres and two-thirds in the smaller, possibly because this plantation has reached it stable production stage and presents large differences between hybrids. The calibres were distributed as follows: J: 2.3\%, XL: 9.8\%, L: 22.7\%, M: 30.5\%, S: $20.4 \%$ and A: $14.2 \%$.

Comparing the hybrids, the following stood out: for J: 'UC-157': 12767(a); 'Eros': 9882(ab) and 'NJ-1123': 9005(abc); for XL: 'NJ-1123': 41124(a); 'Franco': 38958(ab) and 'NJ1192': 37644(ab); for L: 'Ercole': 85083(a); 'NJ-1123': 84700(a); 'Franco': 83872(a) and 'Italo': 83095(a); for M: 'NJ-1123': 118198(a); 'Franco': 116369(a); 'Vittorio': 109645(ab) and 'Ercole': 105984(ab); and for S: 'Giove': 102748(a) and 'NJ-1123': 80530(ab) (Table 3).

Table 3. Calibre distribution (CD) for 13 asparagus genotypes: (Small (S): 6-9 mm; Medium (M): 9-12 mm; Large (L): 12-16 mm; Extra-Large (XL): 16-18 mm; Jumbo (J): >18 $\mathrm{mm})$.

\begin{tabular}{|c|c|c|c|c|c|c|c|c|c|c|c|c|}
\hline Hybrid & J & & $\mathrm{XL}$ & & $L$ & & $M$ & & $S$ & & A & \\
\hline Patron & 2125 & $d$ & 11183 & d & 43103 & d & 58123 & $\mathrm{e}$ & 56310 & cdef & 45078 & \\
\hline NJ-1189 & 8647 & abcd & 29647 & $a b c$ & 2588 & abcd & 70000 & de & 39118 & ef & 19765 & $\mathrm{e}$ \\
\hline Chino & 8647 & $a b c d$ & 471 & $a b c$ & 0941 & abcd & 58882 & $\mathrm{e}$ & 32941 & $f$ & 7176 & cde \\
\hline$C-15$ & 12765 & a & 7588 & $a b c$ & 47765 & cd & 74941 & cde & 52294 & def & 46529 & bcd \\
\hline Early California & 382 & $c d$ & 1824 & cd & 54353 & bcd & 92647 & $a b c d$ & 54765 & def & 24294 & de \\
\hline Eros & 9882 & $a b$ & 28412 & $a b c$ & 68765 & $a b c$ & 83177 & bcde & 39529 & ef & 19765 & e \\
\hline JJ-1192 & 7047 & $a b c d$ & 37645 & ab & 57979 & bcd & 73087 & de & 57012 & bcde & 38657 & cde \\
\hline م & 5385 & bcd & 33273 & $a b c$ & 83095 & a & 103889 & $a b c$ & 58723 & bcde & 32165 & cde \\
\hline Ercole & 3426 & bcd & 24425 & bcd & 85084 & a & 105984 & ab & 65452 & bcd & 44831 & bcd \\
\hline Siove & 2687 & cd & 22188 & cd & 65422 & abcd & 103357 & $a b c$ & 102748 & a & 68541 & ab \\
\hline Vittorio & 6592 & $a b c d$ & 30437 & $a b c$ & 74578 & ab & 109645 & ab & 80530 & $a b c$ & 48518 & oc \\
\hline Fra & 7887 & $a b c d$ & 38959 & ab & 83872 & a & 116369 & a & 63870 & bcd & 43044 & cde \\
\hline VJ-1123 & 9005 & $a b c$ & 41124 & & 84701 & a & 118198 & a & 80530 & ab & 87494 & \\
\hline
\end{tabular}

Distinct letters between indicate significant differences at $P \leq 0.05$.

Fifty-three percent of the productivity achieved fell into the intermediate calibres Large and Medium, with the latter being the predominant category (Figure 3). These calibres are those most in demand by distinct markets (Figure 5). 


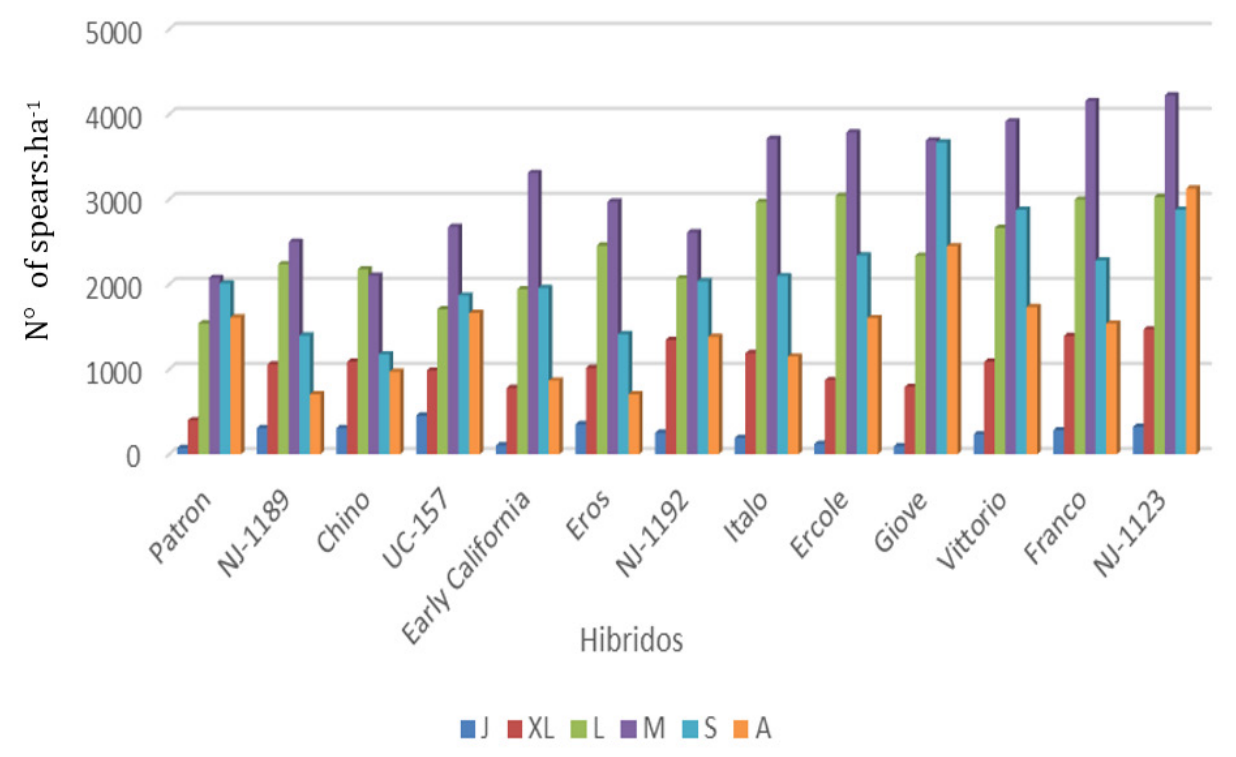

Figure 5. Calibre distribution for 13 asparagus genotypes: (Asparagine (A): $<6 \mathrm{~mm}$; Small (S): 6-9 mm; Medium (M): 9-12 mm; Large (L): 12-16 mm; Extra Large (XL): 16-18 $\mathrm{mm}$; Jumbo (J): >18 mm).

The genotypes that produced the most of the Asparagine category, above the mean, were 'Patrón': 7\%, 'NJ-1123': 7\%; 'Giove': 5\% and 'UC-157': 4\%. The elevated value of this category in these genotypes possibly implies that it would have been advisable in these cases to have discontinued harvesting earlier in the season.

The outstanding production of the J calibre by genotype 'UC-157' was possibly due to the fact that $50 \%$ of the plants are feminine and that these tend to produce larger calibre spears than masculine plants. For the same reason, the all-male Italian hybrids produced a high proportion of intermediate spears.

\section{CONCLUSIONS}

The following conclusions can be drawn from the study:

- The Italian green asparagus genotypes 'Vittorio', 'Franco', 'Giove, 'Ercole' and 'Italo', together with 'NJ-1123', demonstrated better productive behavior at the beginning of the stable production stage, for which their cultivation would be beneficial for the study zone, where the aim is to achieve productivity throughout the economic life of the plantation.

- Fertilisation with ammonium diphosphate during the winter prior to harvest would not influence immediate productivity subsequently achieved.

- It would be advisable to continue evaluating these genotypes in order to verify if their superior behavior is maintained and to determine the influence of winter fertilisation on the productivity in the following year, work currently in progress.

\section{ACKNOWLEDGEMENTS}

We gratefully acknowledge the financial support of the Faculty of Agronomy, UNICEN, and SeCAT, UNICEN.

\section{Literature cited}

Benson, B.L., Mullen, R.J., and Dean, B.B. (1996). Threenew green asparagus cultivars; Apollo, Atlas and Grande and one purple cultivar. Purple Passion. Acta Hortic. 415 (415), 59-65 https://doi.org/10.17660/ActaHortic.1996.415.8.

Castagnino, A.M., Díaz, K.E., Guisolis, A., Marina, J., and Benson, S. Preliminary results of the Fourth International 
Asparagus Cultivar Trial at Azul, Argentina. Acta Hortic. (in press).

Chin, C.K., and Garrison, S.A. (2008). Functional elements from asparagus for human health. Acta Hortic. 776, 219225 https://doi.org/10.17660/ActaHortic.2008.776.27.

Chin, C.K., Garrison, S.A., Shao, Y., Wang, M., Simon, J., Ho, C.T., and Huang, M.T. (2002). Functional elements from asparagus for human health. Acta Hortic. 589, 233-241 https://doi.org/10.17660/ActaHortic.2002.589.32.

Demirkol, O., Adams, C., and Ercal, N. (2004). Biologically important thiols in various vegetables and fruits. J. Agric. Food Chem. 52 (26), 8151-8154 https://doi.org/10.1021/jf040266f. PubMed

Demrkol, O. (2009). Effects of hydrogen peroxide treatment on thiol contents in fresh-cut asparagus (Asparagus officinalis) spears. Int. J. Food Sci. Nutr. 60 (1), 80-88 https://doi.org/10.1080/09637480701602969. PubMed

Drinkwater, J.M., Tsao, R., Liu, R., and Wolyn, D.J. (2014). Genetic variation and heritability of rutin and glutathione concentrations in asparagus spears. Can. J. Plant Sci. 94 (8), 1355-1362 https://doi.org/10.4141/cjps-2014-146.

Fallon, P.G., and Andersen, A.M. (1999). Breeding purple asparagus from tetraploid 'Violetto d'Albenga'. Acta Hortic. 479, 109-113 https://doi.org/10.17660/ActaHortic.1999.479.13.

Fanasca, S., Rouphael, Y., Venneria, E., Azzini, E., Durazzo, A., and Maiani, G. (2009). Antioxidant properties of raw and cooked spears of green asparagus cultivars. Int. J. Food Sci. Technol. 44 (5), 1017-1023 https://doi.org/10.1111/j.1365-2621.2008.01871.x.

FAO. (2018). http://www.fao.org/. Fecha de consulta 11/06/2018.

Fuentes-Alventosa, J.M., Jaramillo, S., Rodríguez-Gutiérrez, G., Cermeño, P., Espejo, J.A., Jiménez-Araujo, A., GuillénBejarano, R., Fernández-Bolaños, J., and Rodríguez-Arcos, R. (2008). Flavonoid profile of green asparagus genotypes. J. Agric. Food Chem. 56 (16), 6977-6984 https://doi.org/10.1021/jf8009766. PubMed

González Castañón, M.L. (1990). Evaluation of male and female asparagus plants Interest in obtaining male or dioecious hybrids. Acta Hortic. 271, 83-89 https://doi.org/10.17660/ActaHortic.1990.271.9.

Guillén, R., Rodríguez, R., Jaramillo, S., Rodríguez, G., Espejo, J.A., Fernández-Bolaños, J., Heredia, A., and Jiménez, A. (2008). Antioxidants from asparagus spears: phenolics. Acta Hortic. 776, 247-253 https://doi.org/10.17660/ActaHortic.2008.776.31.

Han, Y.Y., Fan, S.X., Cheng, J.H., and Fu, J. (2008). Comparative studies on bioactive compounds in different varieties of Asparagus officinalis L. Acta Hortic. 765, 283-286.

Hoberg, E., Ulrich, D., Standhardt, D., and Kecke, S. (1999). Evaluation of Asparagus officinalis L. flavour quality for breeding purposes. Acta Hortic. 479, 135-140 https://doi.org/10.17660/ActaHortic.1999.479.17.

Jones, D.P., Coates, R.J., Flagg, E.W., Eley, J.W., Block, G., Greenberg, R.S., Gunter, E.W., and Jackson, B. (1992). Glutathione in foods listed in the National Cancer Institute's Health Habits and History Food Frequency Questionnaire. Nutr. Cancer 17 (1), 57-75 https://doi.org/10.1080/01635589209514173. PubMed

Lee, E.J., Yoo, K.S., and Patil, B.S. (2010). Development of a rapid HPLC-UV method for simultaneous quantification of protodioscin and rutin in white and green asparagus spears. J. Food Sci. 75 (9), C703-C709 https://doi.org/10.1111/j.1750-3841.2010.01824.x. PubMed

Lipton, W.J. (1990). Postharvest biology of fresh asparagus. Hortic. Rev. (Am. Soc. Hortic. Sci.) 12, 69-149.

Maeda, T., Kakuta, H., Sonoda, T., Motoki, T., Maekawa, K., Suzuki, T., and Oosawa, K. (2008). Differences in antioxidative contents of asparagus related to cultivars and seasonal change under various cultural conditions of the mother-fern culture. Acta Hortic. 776, 227-233 https://doi.org/10.17660/ActaHortic.2008.776.28.

Maeda, T., Honda, K., Sonoda, T., Motoki, S., Inoue, K., Suzuki, T., Oosawa, K., and Suzuki, M. (2010). Light condition influences rutin and polyphenol contents in asparagus spears in the mother-fern culture system during the summer-autumn harvest. J. Jpn. Soc. Hortic. Sci. 79 (2), 161-167 https://doi.org/10.2503/jjshs1.79.161.

Mills, B.J., Stinson, C.T., Liu, M.C., and Lang, C.A. (1997). Glutathione and cyst(e)ine profiles of vegetables using high performance liquid chromatography with dual electrochemical detection. J. Food Compos. Anal. 10 (2), 90-101 https://doi.org/10.1006/jfca.1997.0526.

Minagri (Ministerio de Agricultura y Riego). (2016). http://www.minagri.gob.pe/portal/especial-iv-cenagro/28sector-agrario/ esparragos/234-esparragos?start=2. Accessed June 13, 2018.

Motoki, S., Kitazawa, H., Maeda, T., Suzuki, T., Chiji, H., Nishihara, E., and Shinohara, Y. (2012). Effects of various asparagus production methods on rutin and protodioscin contents in spears and cladophylls. Biosci. Biotechnol. Biochem. 76 (5), 1047-1050 https://doi.org/10.1271/bbb.120143. PubMed

Qiang, Z., Demirkol, O., Ercal, N., and Adams, C. (2005). Impact of food disinfection on beneficial biothiol contents in vegetables. J. Agric. Food Chem. 53 (25), 9830-9840 https://doi.org/10.1021/jf051359f. PubMed 
Rodkiewicz, T. (2008). Vitamin C changes and total antioxidant activity offers hand stored green asparagus spears. Acta Hortic. 776, 235-238 https://doi.org/10.17660/ActaHortic.2008.776.29.

Rodríguez, R., Jaramillo, S., Rodríguez, G., Espejo, J.A., Guillén, R., Fernández-Bolaños, J., Heredia, A., and Jiménez, A. (2005). Antioxidant activity of ethanolic extracts from several asparagus cultivars. J. Agric. Food Chem. 53 (13), 5212-5217 https://doi.org/10.1021/jf050338i. PubMed

SAGPyA. (2007). Secretaría De Agricultura, Ganadería, Pesca y Alimentos. Protocolo de calidad para espárrago fresco. Resolución SAGPyA № 249/2007. http://www.alimentosargentinos.gov.ar/programa_calidad/ diferenciacion/sello/SAA010_Esparrago_v08.pdf.

Saito, M., Rai, D.R., and Masuda, R. (2000). Effect of modified atmosphere packaging on glutathione and ascorbic acid content of asparagus spears. J. Food Process. Preserv. 24 (3), 243-251 https://doi.org/10.1111/j.17454549.2000.tb00416.x.

Schwarzbach, A., Schreiner, M., and Knorr, D. (2006). Effect of cultivars and deep freeze storage on saponin content of white asparagus spears (Asparagus officinalis L.). Eur. Food Res. Technol. 222 (1-2), 32-35 https://doi.org/10.1007/s00217-005-0011-4.

Siomos, A.S. (2018). Review The quality of asparagus as affected by preharvest factors. Sci. Hortic. (Amsterdam) 233, 510-519 https://doi.org/10.1016/j.scienta.2017.12.031.

Stoffyn, O.M., Tsao, R., Liu, R., and Wolyn, D.J. (2012). The effects of environment and storage on rutin concentration in two asparagus cultivars grown in southern Ontario. Can. J. Plant Sci. 92 (5), 901-912 https://doi.org/10.4141/cjps2012-022.

Ulrich, D., and Hoberg, E. (2002). Flavor analysis in asparagus breeding. Acta Hortic. 589, 281-285 https://doi.org/10.17660/ActaHortic.2002.589.38.

Ulrich, D., Hoberg, E., Bittner, T., Engewald, W., and Meilchem, K. (2001). Contribution of volatile compounds to the flavor of cooked asparagus. Eur. Food Res. Technol. 213 (3), 200-204 https://doi.org/10.1007/s002170100349.

Zacharis, C.K., Tzanavaras, P.D., and Zotou, A. (2011). Ethyl propiolate as a post-column derivatization reagent for thiols: development of a green liquid chromatographic method for the determination of glutathione in vegetables. Anal. Chim. Acta 690 (1), 122-128 https://doi.org/10.1016/j.aca.2011.02.003. PubMed 